\title{
The progressive adoption of a circular economy by businesses for cleaner production: an approach from a regional study in Spain
}

\author{
Alfonso Aranda-Usón ${ }^{1}$, Pilar Portillo-Tarragona ${ }^{2}$, Sabina Scarpellini ${ }^{3 *}$, Fernando \\ Llena-Macarulla ${ }^{4}$ \\ 1 University of Zaragoza - Department of Accounting and Finance and CIRCE Research \\ Institute; alaranda@unizar.es \\ 2 University of Zaragoza - Department of Accounting and Finance; portillo@unizar.es \\ 3 University of Zaragoza - Department of Accounting and Finance and CIRCE Research \\ Institute; sabina@unizar.es \\ 4 University of Zaragoza - Department of Accounting and Finance; fllena@unizar.es \\ * Correspondence: sabina@unizar.es; Tel.: +34-976762090
}

\begin{abstract}
The literature on the circular economy at the micro-level has mainly focused on the analysis of the circular business model and implementation of different circular-related practices, but the process of adoption by businesses of the circular economy is still under investigation. Therefore, through a study in the region of Aragón, Spain, the main circular economy-related activities implemented by a sample of 52 businesses are classified into four levels as an approach to the change process that firms can undergo to adopt the circular economy. In summary, it can be stated that circular economy-related activities are being introduced by businesses progressively, from a minor activity to a greater number of activities, but that these activities do not respond to the incremental closure of material loops within the circular economy framework. The applied indicators enhance the knowledge on the environmental management accounting applied to the CE for the reporting and the relations with stakeholders. In addition, the measurement of the introduction of the circular economy in different businesses is relevant for practitioners and for policy makers, in response to the institutional initiatives for the promotion of the circular economy at the territorial level.
\end{abstract}

\section{Introduction}

In response to global environmental degradation, some firms have become proactive in their attempts to introduce cleaner production processes and to adopt the principles of a circular economy (CE). The CE is an alternative to the linear model, allowing for the added 
Aranda-Usón, A., Portillo-Tarragona, P. Scarpellini, S., Llena-Macarulla, F. (2019 on-line) The progressive adoption of a circular economy by businesses for cleaner production: An approach from a regional study in Spain. Journal of Cleaner Production. Vol. 247(2020) 119648 - https://doi.org/10.1016/j.jclepro.2019.119648

value of products to be maintained for as long as possible while contributing to waste reduction.

The multiple articulations of the CE have made it difficult to converge on a single definition (Masi et al., 2017). Yuan et al. (2006) pointed out that the main objectives of the $\mathrm{CE}$ are the reduction of the flow of materials, the achievement of energy efficiency, and the idea that natural and social capital must be constantly renewed through multiple phases. In summary, in a CE, fewer materials are required to produce a constant level of products, either because of a reduction in the amount of resources used or because raw materials are replaced with recycled ones (Figge et al., 2017). The CE, once fully developed, will promote high value material cycles instead of recycling only for low value raw materials as in traditional recycling (Ghisellini et al., 2016).

In the literature, the $\mathrm{CE}$ is an emerging topic, and research has been gaining ground in academics, particularly at the macro-level (Merli et al., 2018). Scholars have also studied the role of firms in the development of the CE at the micro-level (Lewandowski, 2016). However, only a few authors have investigated how firms might integrate the principles of a CE into their business practices (Katz Gerro and López Sintas, 2019). To date, in studying the $\mathrm{CE}$ at the micro level, academics have focused their research on the factors that affect the commitment of private firms to a CE, existing barriers and incentives for its introduction (Garcés-Ayerbe et al., 2019; Govindan and Hasanagic, 2018; Zhu et al., 2014) and the impact of circularity on the business model (Pieroni et al., 2019).

Specifically regarding the adoption of the CE in businesses, Mathews and Tan (2011) indicated that the transformation from a traditional linear economy to a circular one requires evolutionary processes in which dynamic linkages are established gradually over time. It could therefore be assumed that a firm's process of adopting the CE will occur gradually to allow for meeting the need for organisational learning (Crossan et al., 1999). This pattern was experienced, for example, in environmental proactivity and in eco-innovation management (Garcés-Ayerbe et al., 2016). Nonetheless, there has been limited research on the components that are crucial to the success of the CE in businesses (Witjes and Lozano, 2016).

Some research on metrics for quantifying circularity of products has been performed (Linder et al., 2017), but it does not include the development of indicators for measuring the adoption of the CE by a company as a whole. This field of research is not without difficulties since there is still no consensus on how to measure the different CE-related activities 
Aranda-Usón, A., Portillo-Tarragona, P. Scarpellini, S., Llena-Macarulla, F. (2019 on-line) The progressive adoption of a circular economy by businesses for cleaner production: An approach from a regional study in Spain. Journal of Cleaner Production. Vol. 247(2020) 119648 - https://doi.org/10.1016/j.jclepro.2019.119648

implemented by companies. Therefore, an objective of this study is to analyse how companies adopt the $\mathrm{CE}$ principles internally to enhance the knowledge about the measurement of the engagement of businesses in the CE. Moreover, to the best of our knowledge, only a few empirical studies have measured the introduction of circular activities in different industries within a territory (Aranda-Usón et al., 2018). Thus, another objective of this study is to fill this gap measuring the $\mathrm{CE}$ introduction in businesses from a regional perspective, as a subject that has been little explored in the academic literature.

Based on the previous arguments, in this study, the adoption of the CE in businesses is analysed in Aragón, a region located in the northeast of Spain, which was selected with the aim of understanding how companies have undertaken actions towards implementing the CE.

The remainder of the article is structured as follows. Following a review of the literature summarised in the background section, the methodology of the analysis and the regional study are described. The results are summarised and discussed from a regional perspective to outline the main conclusions and potential avenues for future research.

\section{Background}

The approach used in this study is not specifically theory driven, and the research objective is to generate knowledge about how to measure the introduction of the $\mathrm{CE}$ in businesses in a territory. Nevertheless, a summarised theoretical approach is presented in the following paragraphs to outline the general scope of the research.

Conceptual discussions of the CE are still in their infancy among scholar, and the literature in the micro field is only emerging. Theory has been mainly approached for discussing the CE concept (Kalmykova et al., 2018) or its taxonomy (Urbinati et al., 2017), and there is a need for deeper study of the concept, its units of analysis, and the theoretical basis of the CE (Korhonen et al., 2018). Some of the most relevant theoretical influences are cradle-to-cradle and industrial ecology (Geissdoerfer et al., 2017). In the CE literature at the micro-level, some studies have been conducted in the framework of stakeholder theory (Walls and Paquin, 2015), institutional theory (Zeng et al., 2017), the resource-based view (Aranda-Usón et al., 2019), the dynamic capabilities theoretical framework (Katz Gerro and López Sintas, 2019) or the business model theory (Pieroni et al., 2019). Walls and Paquin (2015) pointed out that the industrial symbiosis specific literature also remains fragmented theoretically and has developed separately from corporate environmental strategy, in which the focus is mostly on intra-firm, rather than inter-firm, action. Thus, the CE could require 
Aranda-Usón, A., Portillo-Tarragona, P. Scarpellini, S., Llena-Macarulla, F. (2019 on-line) The progressive adoption of a circular economy by businesses for cleaner production: An approach from a regional study in Spain. Journal of Cleaner Production. Vol. 247(2020) 119648 - https://doi.org/10.1016/j.jclepro.2019.119648

significant re-examination of much of current theory and lead to new practice (Murray et al., 2017).

From another perspective, based on the theoretical premise that the economic system is an open subsystem of the ecological system of land and limited resources, a certain environmental capacity is related to the CE (Li et al., 2010). At a theoretical level, Geng et al. (2009) stated that the CE model fits closely with ecological modernisation theory. However, the theoretical frameworks that can be applied to the CE principles in a spatial context has not clearly defined, and the measurement methods that have been applied at regional levels have achieved segmented or partial results to date. It has to be taken into account that the environmental behaviour of a company in a CE context is influenced not only by internal factors but also by its external context (Liu and Bai, 2014). Therefore, there is no doubt that stakeholders play important roles in the adoption by companies of the CE principles (Lieder and Rashid, 2016).

From a spatial perspective, the theoretical framework of analysis must consider the necessity of engaging with all relevant stakeholders (Pomponi and Moncaster, 2017), the collaborative requirements of the CE (Pieroni et al., 2019), the role of wider systems in business and accounting decisions within environmental management and sustainability reporting (Murray et al., 2017), and the importance of legitimacy among key stakeholders at different positions in the value chain needed for a CE (Linder et al., 2017).

It is not our intention to revisit these different bodies of literature; rather, we wished to examine the literature on these fields in a common framework of analysis, exploring the potential for adding something of substance to the debate over the measurement of the CE at the micro-level from a territorial perspective. Nevertheless, in this study, the consideration of multiple stakeholders beyond the firm-centric view (Reike et al., 2018) brings us closer to the stakeholders theory when contemplating research focusing on the adoption of the $\mathrm{CE}$ at the micro-level.

\subsection{The challenges of adopting the circular economy by firms}

Academics have mostly addressed the measurement of the CE from the perspectives of resource productivity, critical raw materials scarcity, or the reduction of solid waste, emissions and pollution (Lieder and Rashid, 2016). Although these aspects have been analysed in the CE literature, the development of an integrated indicator to measure the level of adoption of the CE by businesses at the organisation level is still under discussion. 
Aranda-Usón, A., Portillo-Tarragona, P. Scarpellini, S., Llena-Macarulla, F. (2019 on-line) The progressive adoption of a circular economy by businesses for cleaner production: An approach from a regional study in Spain. Journal of Cleaner Production. Vol. 247(2020) 119648 - https://doi.org/10.1016/j.jclepro.2019.119648

In the absence of a recognised method for assessing how effectively a product or a whole company makes the transition from a linear model of operation to a circular model, Smol et al. (2017) recommended indicators based on eco-innovation, but they referred exclusively to technical cycles and materials from non-renewable sources. Elia et al. (2017) contributed to filling the current gap in the environmental evaluation of CE strategies at the micro-level with a taxonomy of index-based methodologies. These authors pointed out the so-called material circularity indicator (Ellen MacArthur Foundation and Granta Design, 2015) that can be adopted both at a product level and at a company level to measure how restorative flows are maximised and linear flows minimised. Di Maio and Rem (2015) introduced the 'circular economy index' to measure the circularity level of a product as the ratio of the material value produced by the recycler (market value) to the material value entering the recycling facility.

Katz-Gerro and López Sintas (2018) provided a picture of EU businesses engaged in CE-related activities and pointed out the heterogeneity in the 28 current EU countries regarding patterns of circular business. Franco (2017) noted the lack of research at the microlevel, especially when considering that essential activities pertinent to firms that can be considered pre-requisites for successful deployment of the CE (Lieder and Rashid, 2016). Urbinati et al. (2017) introduced a promotion dimension of the CE principle, which becomes part of a company's positioning against competitors, and Linder et al. (2017) added to the previous approach with plausible incentives for firms to attempt to present circularity values that are as high as possible. However, these researchers did not study the degree of adoption of the $\mathrm{CE}$ in firms located in a given region, and they confirmed the need to develop standardised methods for measuring circularity at the micro-level that include both businesses and products.

Some of the studies that partially described the activities that companies perform within the framework of the $\mathrm{CE}$ can be found in recent reviews of the literature in this field, summarised in Table 1. In summary, the CE-related activities performed by businesses that have been analysed in the literature can be classified into four groups: I) activities that have been implemented for waste treatment and recycling (Chen et al., 2010); II) activities including dematerialisation secondary raw materials and waste recovery (Winkler, 2011); III) activities related to eco-design (Kama, 2015); and IV) activities in which industrial ecology and/or symbiosis is considered (Mathews and Tan, 2011; Winkler, 2011). However, there is no consensus regarding the best method of capturing distinct CE-related activities, nor has it 
Aranda-Usón, A., Portillo-Tarragona, P. Scarpellini, S., Llena-Macarulla, F. (2019 on-line) The progressive adoption of a circular economy by businesses for cleaner production: An approach from a regional study in Spain. Journal of Cleaner Production. Vol. 247(2020) 119648 - https://doi.org/10.1016/j.jclepro.2019.119648

discussed how firms can in practice adapt their business models to this new paradigm (Urbinati et al., 2017).

Furthermore, the descriptions of the activities introduced by businesses do not reveal the process that firms undergo in adopting the CE. The literature does not elucidate whether the adoption of new CE-related activities by businesses is undertaken specifically to increase their level of circularity or to respond to other demands. To investigate the research gap, a first research question was formulated:

- RQ1) How do companies in a region adopt activities related to the CE?

In this scenario, it must also be considered that the $\mathrm{CE}$ is influenced by geographical proximity since the availability of activities at local and regional levels helps to reduce the costs associated with broader circuits involving greater numbers of transactions (Stahel, 2013). Local and regional authorities play important roles in both the launch of and the transition to a CE (Yi and Liu, 2015) since the implementation of a circular business model is so closely tied to the territories within which firms operate. Based on these considerations, a second line of inquiry focusing on the regional level analysis was defined and is developed in the following section.

\subsection{The circular economy in businesses at the regional level}

Although the introduction of the circular principles in organisations is increasing, the engagement of firms with the CE-related practices remains weak (Zamfir et al., 2017). In the micro-field, commitment to sustainable development and the CE has been consolidated with the help of environmental regulations and public incentives (Ghisellini et al., 2018; Hu et al., 2018). Different initiatives to promote the $C E$ at the regional level have been launched in a number of geographical areas, including Europe (European Commision, 2015; Gharfalkar et al., 2015), Japan (Despeisse et al., 2015; Van Berkel et al., 2009), China (Mathews and Tan, 2011) and the United States (Zink and Geyer, 2017). In particular, China promulgated specific laws about the CE that had consequences at technological, economic and social levels (Dajian, 2008). Thus, at regional level, several studies have been focused on the Chinese development of the $\mathrm{CE}$ and the metrics than could be applied for its measurement in a territory (Geng et al., 2012, 2009), for waste management (Chen et al., 2010), or for the businesses' activity as agents of CE deployment (Ghisellini et al., 2018; Zhu et al., 2014) 
Aranda-Usón, A., Portillo-Tarragona, P. Scarpellini, S., Llena-Macarulla, F. (2019 on-line) The progressive adoption of a circular economy by businesses for cleaner production: An approach from a regional study in Spain. Journal of Cleaner Production. Vol. 247(2020) 119648 - https://doi.org/10.1016/j.jclepro.2019.119648

In summary, different factors can influence the adoption of CE-related activities by businesses, such as the industrial situation, regional businesses, the innovation level, the legislative profile at the regional or local level and the state of CE development within a given region. In the area of waste management, Fletcher et al. (2018) emphasised the role of policies in the transition to a CE: governments facilitate the introduction of CE principles through incentives to facilitate resource recovery and to guarantee investment. Regulations and public support increase the adoption of sustainable manufacturing practices, such as the CE (Moktadir et al., 2018), and the introduction of broader circular principles related to the exchange of goods and services has been encouraged through policies promoting social responsibility in companies (Liu and Yang, 2018) and supporting CE-oriented strategies (Ormazabal et al., 2018). However, research about the uptake of the CE in businesses at the regional level remains limited. In an attempt to fill this gap in the research, the following research question was formulated:

- RQ2) Is the adoption of the CE-related activities by companies influenced by the territories in which they are located?

The line of inquiry drawn in this second research question focuses on the analysis of the $\mathrm{CE}$ at the micro-level in a specific region. To answer the two research questions and to enhance our knowledge about the measurement of the $\mathrm{CE}$ in businesses, a qualitative methodology was designed to be applied to a study described in the following section.

\section{Research design and regional study}

The research method was designed to provide a qualitative analysis of a regional study in Aragón in the northeast of Spain, in response to a commitment of the regional government.

Drawing on the available literature and the experience of the researchers, in the initial phase of this study, a selection of CE-related activities that could currently be implemented by companies in the region was made based on the proposal of Aranda-Usón et al. (2019). The variables designed to measure the selected activities and the main literature to justify this selection are summarised in Table 1.

\begin{tabular}{|c|c|}
\hline CE-related activities & Selection of contributions \\
\hline $\begin{array}{l}\text { 01. Reduction of the environmental } \\
\text { impact of the company }\end{array}$ & $\begin{array}{l}\text { (Dong-her et al., 2018; Elia et al., 2017; Linder et al., 2017; } \\
\text { Manninen et al., 2018) }\end{array}$ \\
\hline 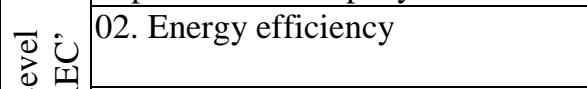 & $\begin{array}{l}\text { (Kalmykova et al., 2018; Katz Gerro and López Sintas, 2019; Stewart } \\
\text { and Niero, 2018) }\end{array}$ \\
\hline 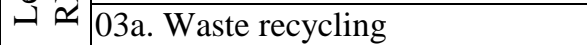 & (Katz Gerro and López Sintas, 2019; Santolaria et al., 2011) \\
\hline
\end{tabular}


Aranda-Usón, A., Portillo-Tarragona, P. Scarpellini, S., Llena-Macarulla, F. (2019 on-line) The progressive adoption of a circular economy by businesses for cleaner production: An approach from a regional study in Spain. Journal of Cleaner Production. Vol. 247(2020) 119648 - https://doi.org/10.1016/j.jclepro.2019.119648

\begin{tabular}{|c|c|c|}
\hline \multirow{4}{*}{ 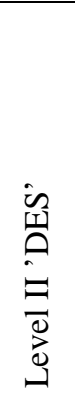 } & 04. Renewable energy & $\begin{array}{l}\text { (Elia et al., 2017; European Commission, 2016; Katz Gerro and } \\
\text { López Sintas, 2019; Manninen et al., 2018; Stewart and Niero, 2018) }\end{array}$ \\
\hline & $\begin{array}{l}\text { 05. Design for resource efficiency } \\
\text { (“dematerialisation”) }\end{array}$ & $\begin{array}{l}\text { (Kalmykova et al., 2018; Katz Gerro and López Sintas, 2019; Liu and } \\
\text { Bai, 2014; Manninen et al., 2018; Miroshnychenko et al., 2017; } \\
\text { Moreno et al., 2016; Ormazabal et al., 2018; Stewart and Niero, } \\
\text { 2018) }\end{array}$ \\
\hline & 06. Design for resource recovery & $\begin{array}{l}\text { (Liu and Bai, 2014; Manninen et al., 2018; Miroshnychenko et al., } \\
\text { 2017; Moreno et al., 2016; Stewart and Niero, 2018) }\end{array}$ \\
\hline & $\begin{array}{l}\text { 07. “Secondary raw materials” } \\
\text { (recycled) }\end{array}$ & $\begin{array}{l}\text { (Manninen et al., 2018; Santolaria et al., 2011; Stewart and Niero, } \\
\text { 2018) }\end{array}$ \\
\hline \multirow{3}{*}{ 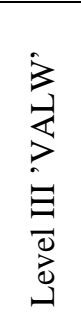 } & 08. Product-life extension & $\begin{array}{l}\text { (Bakker et al., 2014; Bocken et al., 2016; Elia et al., 2017; Franco, } \\
\text { 2017; Linder et al., 2017; Manninen et al., 2018; Moreno et al., 2016; } \\
\text { Stewart and Niero, 2018) }\end{array}$ \\
\hline & $\begin{array}{l}\text { 09. Design for upgradability } \\
\text { and multifunctionality }\end{array}$ & $\begin{array}{l}\text { (Bocken et al., 2016; De los Rios and Charnley, 2017; Kalmykova et } \\
\text { al., 2018; Moreno et al., 2016; Santolaria et al., 2011) }\end{array}$ \\
\hline & 10. Eco-innovation & $\begin{array}{l}\text { (de Jesus et al., 2018; Dong-her et al., 2018; Ormazabal et al., 2018; } \\
\text { Portillo-Tarragona et al., 2018; Prieto-Sandoval et al., 2018; } \\
\text { Walendowski et al., 2014) }\end{array}$ \\
\hline \multirow{3}{*}{ 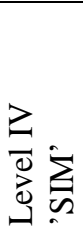 } & 03b. Internal recycling & $\begin{array}{l}\text { (Dong-her et al., 2018; Liu and Bai, 2014; Ormazabal et al., 2018; } \\
\text { Stewart and Niero, 2018) }\end{array}$ \\
\hline & 11. Energy waste recovery & $\begin{array}{l}\text { (Bocken et al., 2016; Huysman et al., 2017; Manninen et al., 2018; } \\
\text { Ormazabal et al., 2018; Singh and Ordóñez, 2016) }\end{array}$ \\
\hline & $\begin{array}{l}\text { 12. Industrial symbiosis and sharing } \\
\text { (or similar) }\end{array}$ & $\begin{array}{l}\text { (Daddi et al., 2017; Kalmykova et al., 2018; Stewart and Niero, 2018; } \\
\text { Yang and Feng, 2008) }\end{array}$ \\
\hline
\end{tabular}

Table 1. Main CE-related activities classified into four levels, the selected variables to measure the activities and a selection of authors who have studied them within the framework of the CE.

In order to enhance the results obtained by Scarpellini et al. (2019) and Aranda-Usón et al. (2018), an innovative contribution of this study is the classification of the diverse CErelated activities that businesses are adopting in the region into four levels considering the material loops closure that could be achieved in terms of the CE. To this end, the activities included in group I, defined as level I 'REC', are mostly related to recycling and energy efficiency and are considered as the first stage of CE adoption because they are frequently introduced by industries, while the so-called level IV SIM group of activities includes industrial symbiosis solutions or collaborative circular practices that are not frequently implemented and are the most advanced stages of CE adoption (European Commission, 2018a, 2018b). The second group, defined as level II 'DES', includes activities of dematerialisation, renewables and secondary raw materials. Finally, other eco-innovations and eco-design for circular thinking are classified into level III 'VALW'.

This grouping of activities was tested through semi-structured interviews conducted to obtain the opinions of experts about the processes that firms implement when they introduce the $\mathrm{CE}$ in the region. In addition, a questionnaire was sent to a sample of firms located in the region as a complementary analysis to collect the opinions of managers about the introduction of CE-related activities. The validity of the integration of semi-structured interviews and 
Aranda-Usón, A., Portillo-Tarragona, P. Scarpellini, S., Llena-Macarulla, F. (2019 on-line) The progressive adoption of a circular economy by businesses for cleaner production: An approach from a regional study in Spain. Journal of Cleaner Production. Vol. 247(2020) 119648 - https://doi.org/10.1016/j.jclepro.2019.119648

questionnaires applied to a qualitative analysis has been demonstrated for regional studies (Marco-Fondevila et al., 2018; Marco et al., 2019). This integrated method responds to the possible limitations of interviews with stakeholders pointed out by Kirchherr et al. (2017).

In summary, multiple sources of data were obtained (Table 2).

\begin{tabular}{|c|c|c|}
\hline Data Source & Questions & Description \\
\hline Interviewees & $\begin{array}{l}\text { - Relevance of the CE for businesses in the region } \\
\text { - Level of introduction of the CE in regional businesses } \\
\text { - Ranking of the } 4 \text { levels of CE-related activities } \\
\text { - Opinions of experts about the CE-related activities that could be } \\
\text { adopted by businesses } \\
\text { - Opinions of experts about the evolution of the level of interest in the } \\
\text { CE of regional businesses }\end{array}$ & $\begin{array}{l}\text { Semi-structured/ } \\
\text { open questions } \\
\text { Likert scale }^{1} \\
\text { ranking ( } 4_{\text {levels }^{2} \text { ) }}\end{array}$ \\
\hline Questionnaires & $\begin{array}{l}\text { - Measurement of the } 4 \text { levels of the CE-related activities introduced } \\
\text { by businesses via the following variables: } \\
\text { 01- \% of company's total revenues invested in innovative equipment } \\
\text { to reduce the company’s environmental impact } \\
\text { 02- \% of equipment or facilities replaced and/or improved for energy } \\
\text { efficiency } \\
\text { 03- \% of recycling waste (total) } \\
\text { 04- \% of processes/equipment replaced and/or improved to exploit } \\
\text { renewables } \\
\text { 05- \% of the products' design or services modified to reduce the } \\
\text { resource intensity } \\
\text { 06- \% of the products' design or services modified to increase their } \\
\text { recyclability (waste prevention) } \\
\text { 07- \% of resources replaced by other fully recycled materials } \\
\text { 08- \% of the products' design or services modified to extend their } \\
\text { durability and reparability } \\
\text { 09- \% of the products' design or services modified to increase their } \\
\text { functions and upgradability } \\
\text { 10- \% of the company’s total revenue invested in eco-innovation } \\
\text { (other activities) } \\
\text { 11- \% of recycling waste within the company itself } \\
\text { 12- \% of total revenue invested in energy valorisation of waste } \\
\text { 13- \% of recycling waste in shared facilities with other companies and } \\
\text { industrial symbiosis. }\end{array}$ & $\begin{array}{l}\text { Likert scale and } \\
\text { other scales }\end{array}$ \\
\hline
\end{tabular}

Table 2. Entries in data display and main variables.

The text of the interviews was based on the existing literature in this field and sent to a group of 21 experts considered key informants because of their knowledge about the CE at the regional level. The final list of interviewees was elaborated according to the guidelines of the regional government and it proportionally represented the main groups of stakeholders, including society (social agents), administration and the business sector, all of which

1 To facilitate the analysis of the information using a Microsoft Excel spreadsheet, the interviewees were asked to classify some of their answers using a Likert scale, ranging from 0 to 10 , with 0 expressing total disagreement or a perception of the statement's irrelevance and 10 expressing total agreement or a perception of the statement as highly relevant.

${ }^{2}$ To rank the CE-related activities, the opinions of the experts were classified into three categories: 'irrelevant or only slightly relevant' (from 0 to 3 points); 'moderately relevant' (from 4 to 7 points); and relevant' (8 or more points). 
Aranda-Usón, A., Portillo-Tarragona, P. Scarpellini, S., Llena-Macarulla, F. (2019 on-line) The progressive adoption of a circular economy by businesses for cleaner production: An approach from a regional study in Spain. Journal of Cleaner Production. Vol. 247(2020) 119648 - https://doi.org/10.1016/j.jclepro.2019.119648

contribute to the responsible behaviour of companies (Camilleri, 2017), in line with the three main stakeholder categories pointed out by Banaitè and Tamošiūnienè (2016) for a CE (Table 9). The interviews, each lasting approximately 30 minutes, were recorded, transcribed and analysed for trends and patterns of response (Dolowitz and Medearis, 2009).

The selection of the sample of businesses was based on firms that operate in sectors with potential for engaging with the $\mathrm{CE}$, such as those related to technologies included in the 'Best Available Techniques' -- the so-called 'BREFs': industrial; transport and logistics; waste; extractive industries; the manufacturing industry; electricity, gas, steam and air conditioning supply; water supply; sewerage; waste management; transport; and storage. In these sectors, the introduction of the $\mathrm{CE}$ is currently considered technologically more feasible, in line with other studies focusing on pro-environmental change (Rivera-Torres et al., 2015) or ecoinnovation (Garcés-Ayerbe et al., 2016). In addition, the strategic sectors in the region of environmental services and logistics and transport were also considered according to the RIS3 regional specialisation (Gobierno de Aragón, 2015).

This complementary analysis was conducted within the framework of a collaborative R\&D project undertaken in the northeast of Spain. The surveys were sent to the managers of companies directly involved in eco-innovation, eco-design and environmental investments related to the $\mathrm{CE}$ or to the environmental managers of the companies. In the end, 52 valid observations were obtained from firms located in the region of Aragón, identified by their value added tax (VAT) identification numbers. Table 3 summarises the characteristics of the sample.

\begin{tabular}{|c|c|c|c|c|c|c|c|}
\hline Sector & No. & Size & No. & Age & No. & Legal form & No. \\
\hline Food industry & 5 & Large & 14 & $<20$ years & 3 & Cooperative society & 3 \\
\hline Industry sectors & 5 & Medium & 23 & $\geq 20$ and $\leq 39$ years & 19 & Stock corporation & 23 \\
\hline Manufacturing & 20 & Micro & 9 & $\geq 40$ and $\leq 59$ years & 17 & Limited company & 26 \\
\hline Waste sector & 4 & Small & 6 & $>60$ years & 13 & & \\
\hline Service sector & 15 & & & & & & \\
\hline Transport and logistics & 3 & & & & & & \\
\hline
\end{tabular}

Table 3. Main characteristics of the firms integrated in the sample (number of firms)

\section{Main findings and discussion}

\subsection{The circular economy in businesses at the regional level}

The experts were asked to define the relevance of each group of CE-related activities when regional firms introduce the CE (Table 4). 
Aranda-Usón, A., Portillo-Tarragona, P. Scarpellini, S., Llena-Macarulla, F. (2019 on-line) The progressive adoption of a circular economy by businesses for cleaner production: An approach from a regional study in Spain. Journal of Cleaner Production. Vol. 247(2020) 119648 - https://doi.org/10.1016/j.jclepro.2019.119648

\begin{tabular}{|lcccc|}
\hline & Level I - REC & Level II - DES & Level III - VALW & Level IV - SIM \\
Slightly relevant & $20 \%$ & $14 \%$ & $29 \%$ & $25 \%$ \\
Moderately relevant & $55 \%$ & $24 \%$ & $24 \%$ & $50 \%$ \\
Relevant & $25 \%$ & $62 \%$ & $48 \%$ & $25 \%$ \\
\hline
\end{tabular}

Table 4. Opinions about the relevance of the four groups of CE-related activities for the regional businesses provided by the experts (\% of respondents).

In summary, the activities included in levels II and III were considered the most relevant and interesting for regional businesses by the majority of the respondents. Level I was classified as moderately relevant because the experts considered that the activities included in this group are the 'first stage of a CE in businesses'. The evaluation offered by the interviewees on this point confirms the predominance of levels II and III but reveals clear differences of opinion by category of interviewee (Table 5).

\begin{tabular}{|lcccc|}
\hline & Level I 'REC' & Level II 'DES' & Level III 'VALW' & Level IV 'SIM' \\
Public Administration & 7.4 & 7.1 & 7.6 & 5.6 \\
Private Sector & 5.3 & 7.6 & 6.9 & 5.9 \\
Society & 4.8 & 5.9 & 4.9 & 5.0 \\
Mean (Likert scale to 10 points) & 5.85 & 6.86 & 6.43 & 5.48 \\
\hline
\end{tabular}

Table 5. Opinions about the relevance of the four groups of CE-related activities for the regional businesses according to the three categories of interviewees.

If the four groups of CE-related activities are ranked from those currently considered most relevant (4 points assigned by the respondents) to those considered least relevant (1 point assigned), intermediate levels are classified with 2 or 3 points (Figure 1). Most of the activities included in the intermediate groups are considered relevant for the introduction of the $\mathrm{CE}$ in regional businesses, with slightly greater relevance for the third group. 


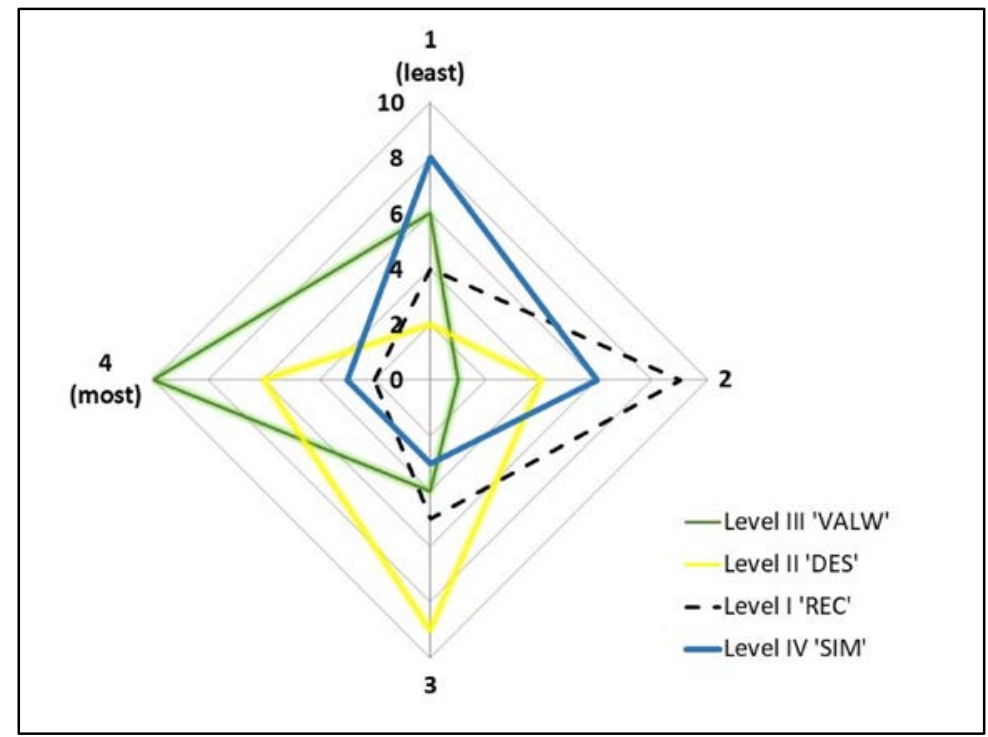

Figure 1. Ranking of the relevance of the four groups of CE-related activities provided by the experts.

When the experts proceeded to order the four groups of activities, they confirmed that companies located in the region have not addressed the activities associated with the more advanced levels of circularity included in the last group (level IV 'SIM'). A representative of public administration answered at this point that 'the CE is not widely implemented at present in the region and is known only by $15 \%$ of private companies'. This opinion is endorsed by some business experts, who declare that 'the general concept of the CE is known by businesses, but only a few of them are implementing it' and that 'it is mostly unknown among SMEs'. In addition, some of the experts said that 'only some large companies are using recycled raw materials and recycling and/or recovering waste within the company itself'. In Table 6, it can be observed that the opinions of the representatives of society differ from the opinions of the representatives of administration and the private sector.

\begin{tabular}{|lcccc|}
\hline & Level I 'REC' & Level II 'DES' & Level III 'VALW' & Level IV 'SIM' \\
Public Administration & 2.6 & 3.1 & 2.3 & 2.0 \\
Private Sector & 2.7 & 3.4 & 1.9 & 2.0 \\
Society & 3.4 & 2.0 & 2.7 & 2,2 \\
Mean (ranked from 0 to 4 points) & 2.90 & 2.86 & 2.27 & 2.06 \\
\hline
\end{tabular}

Table 6. Ranking of the four CE-related groups of activities according to the three categories of interviewees.

In summary, based on the opinion of experts, CE-related activities could be introduced by firms following a partially incremental path because the experts consider that the activities of the second group (level II) are currently the most relevant for the regional businesses, followed closely by those in group III. Based on analysis of the interviews, this result can be 
Aranda-Usón, A., Portillo-Tarragona, P. Scarpellini, S., Llena-Macarulla, F. (2019 on-line) The progressive adoption of a circular economy by businesses for cleaner production: An approach from a regional study in Spain. Journal of Cleaner Production. Vol. 247(2020) 119648 - https://doi.org/10.1016/j.jclepro.2019.119648

explained through the general opinion that the activities related to waste recycling, energy efficiency or similar (level I) had already been implemented by companies and so were not a priority in the region in terms of their relevance to the CE. The lower relevance assigned to the fourth group (level IV) was expected because the activities included in this group are not currently considered feasible in the region. In addition, some experts pointed out that the activities that it contains are expected to be implemented in the medium and long terms.

\subsection{Measurement of the adoption of the $C E$ by businesses}

The level of adoption of CE-related activities in the sample of firms is shown in Table 7 , indicating that most of the companies perform between three and eight activities simultaneously.

\begin{tabular}{|ccc|}
\hline $\begin{array}{l}\text { No. of CE-related } \\
\text { activities }\end{array}$ & $\begin{array}{l}\text { No. of } \\
\text { Firms }\end{array}$ & \% \\
\hline 0 & 7 & $13.46 \%$ \\
\hline 1 & 3 & $5.77 \%$ \\
\hline 2 & 4 & $7.69 \%$ \\
\hline 3 & 5 & $9.62 \%$ \\
\hline 4 & 5 & $9.62 \%$ \\
\hline 5 & 3 & $5.77 \%$ \\
\hline 6 & 7 & $13.46 \%$ \\
\hline 7 & 5 & $9.62 \%$ \\
\hline 8 & 6 & $11.54 \%$ \\
\hline 9 & 3 & $5.77 \%$ \\
\hline 10 & 4 & $7.69 \%$ \\
\hline 11 & 0 & $0.00 \%$ \\
\hline 12 & 0 & $0.00 \%$ \\
\hline TOTAL & 52 & $\mathbf{1 0 0 . 0 0 \%}$ \\
\hline
\end{tabular}

Table 7. Number of CE-related activities performed simultaneously by the firms of the sample.

It is observed that none of the companies in the sample performs more than 10 activities simultaneously, and almost $50 \%$ of the firms perform half or more of the CE-related activities. It is also interesting to analyse whether common behaviours can be detected among firms when they introduce these activities. To this end, the percentages of the companies that perform each CE-related activity are shown in Figure 2 (level I: orange; level II: yellow, level III: green; level IV: blue). 
Aranda-Usón, A., Portillo-Tarragona, P. Scarpellini, S., Llena-Macarulla, F. (2019 on-line) The progressive adoption of a circular economy by businesses for cleaner production: An approach from a regional study in Spain. Journal of Cleaner Production. Vol. 247(2020) 119648 - https://doi.org/10.1016/j.jclepro.2019.119648

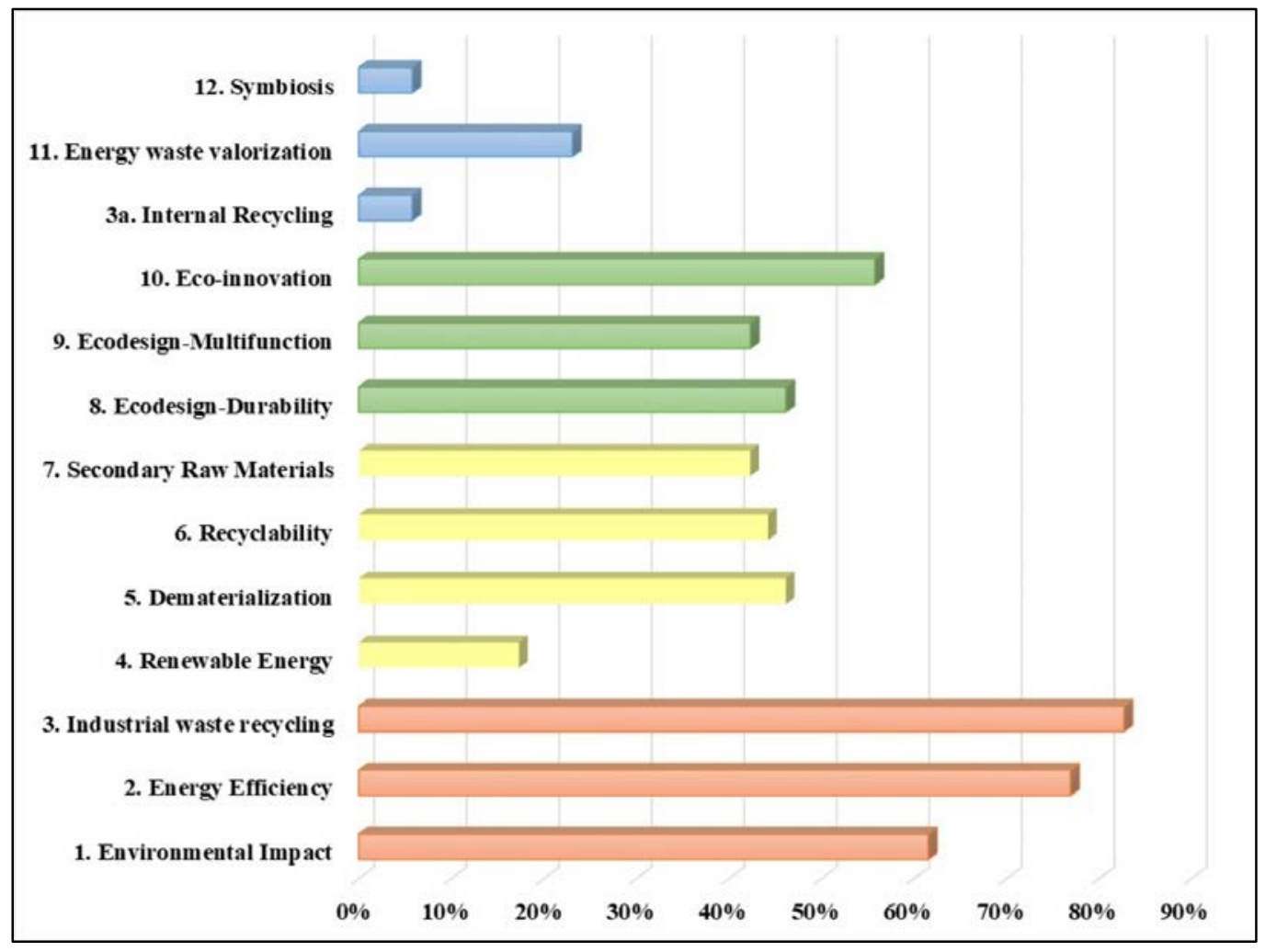

Figure 2. Percentage of firms that perform the CE-related activities classified into four levels.

The most frequently implemented activities are waste recycling and treatment, energy efficiency, reduction of the environmental impact of the company and eco-innovation (55.77\%). Although the general activity of waste recycling and treatment is conducted by a large majority of firms, only a very small percentage of them perform this activity internally (which is a more complex activity, assigned to level IV).

The results obtained through the interviews regarding the relevance of the different groups of activities at the regional level are confirmed in this stage of the study, since the CE-related activities included in the second and third groups (levels II and III) show intermediate levels of adoption by businesses, being performed by $38 \%$ and $48 \%$ of the companies, respectively. The activities included in the first group (level I) are performed by $61.5 \%$ of the companies in the sample, and only $14.42 \%$ of them carry out the activities in the last group (level IV). The particular situation is emphasised of activity number 4 -- which measures the exploitation of renewables by firms, receiving less consideration than other activities of the second group because of a stringent national regulation of self-consumption facilities that limits the net balance and is considered to be a barrier to the exploitation of renewables, such as photovoltaics, in Spanish firms (Gimeno et al., 2018). 
Aranda-Usón, A., Portillo-Tarragona, P. Scarpellini, S., Llena-Macarulla, F. (2019 on-line) The progressive adoption of a circular economy by businesses for cleaner production: An approach from a regional study in Spain. Journal of Cleaner Production. Vol. 247(2020) 119648 - https://doi.org/10.1016/j.jclepro.2019.119648

In Table 8, the level of adoption of different CE-related activities is analysed in relation to the average turnovers of the companies that implement each activity.

\begin{tabular}{|c|l|c|c|c|}
\hline & \multicolumn{1}{|c|}{ CE-related activities } & $\begin{array}{c}\text { Average annual incomes } \\
(€ \text { thousands })\end{array}$ & No. firms & $\%$ \\
\hline \multirow{2}{*}{ Group I } & 1. Environmental Impact & $155,785.71$ & 32 & $61.5 \%$ \\
REC & 3. Energy Efficiency & $165,195.80$ & 40 & $76.9 \%$ \\
\hline \multirow{2}{*}{ Group II } & 4. Renewable Energy & $161,530.62$ & 43 & $82.7 \%$ \\
\hline DES & 6. Dematerialisation & $439,150.34$ & 9 & $17.3 \%$ \\
& 7. Secondary Raw Materials & $240,921.50$ & 24 & $46.2 \%$ \\
\hline \multirow{2}{*}{ Group III } & 8. Eco-design-Durability & $250,999.10$ & 23 & $44.2 \%$ \\
VALW & 10. Eco-design-Multifunction & $271,989.50$ & 22 & $42.3 \%$ \\
\hline \multirow{2}{*}{ Group IV } & 3a. Internal Recycling & $82,595.80$ & 24 & $46.2 \%$ \\
SIM & 11. Energy Waste Valorisation & $16,979.20$ & 29 & $52.3 \%$ \\
\hline \multirow{2}{*}{ 12. Symbiosis } & $211,264.50$ & $35.8 \%$ \\
\hline
\end{tabular}

Table 8. Percentage of firms that perform the CE-related activities classified into four levels and their average turnovers.

In summary, the data indicate that the average turnover of companies is not a significant variable when introducing the CE-related activities of the first group (level I) within the firm. However, for the intermediate-groups of activities (levels II and III), there is a significant relationship between the turnover and the number of companies that implement each activity. Therefore, a higher level of income does not indicate a greater number of activities adopted by the firms. It should be noted that, to invest in some of the activities, such as renewables, internal waste recycling, and energy waste valorisation, a higher level of income is needed.

The level of adoption of the CE-related activities by firms is graphically summarised in Figure 3. 


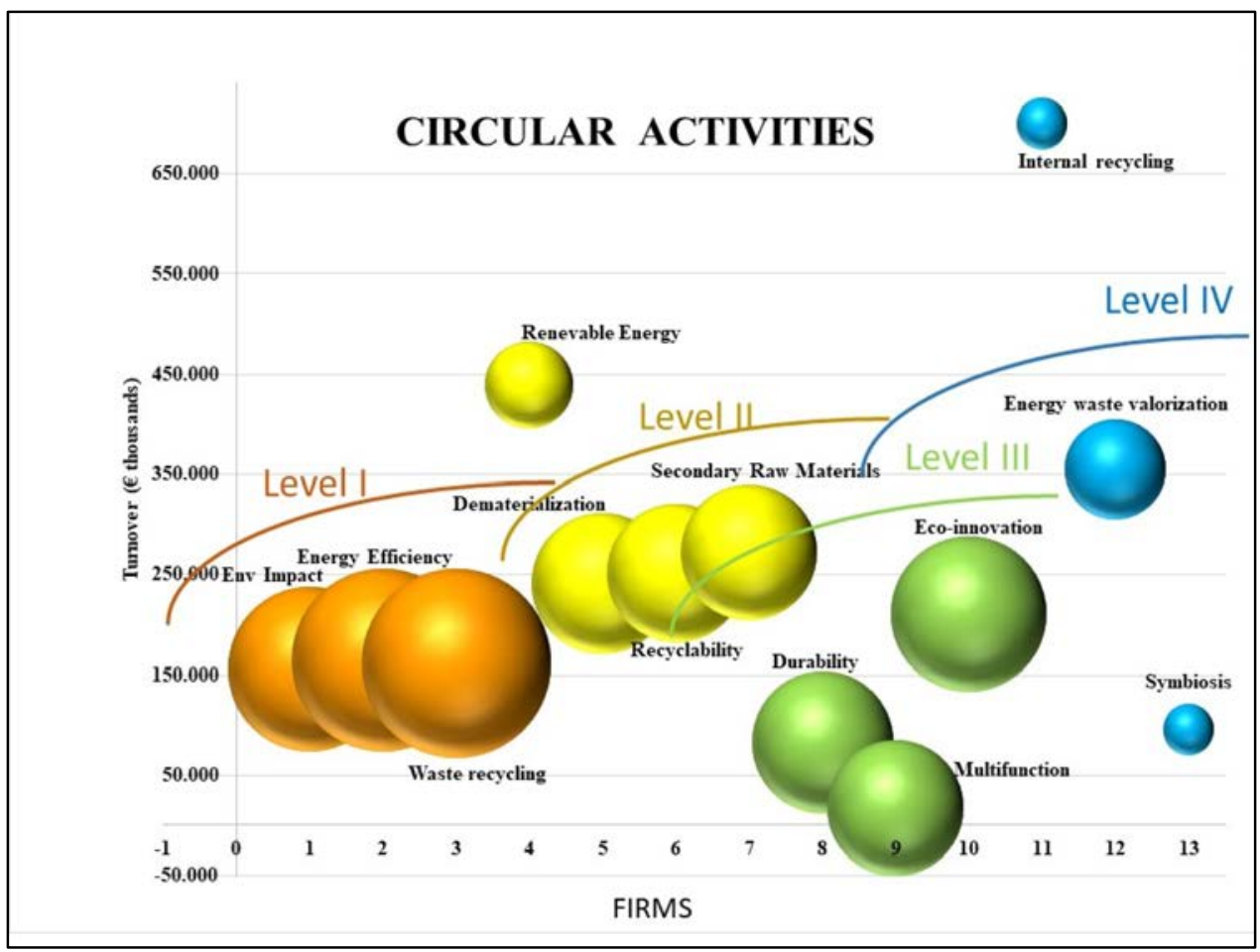

Figure 3. Graphical analysis of the adoption by firms of CE-related activities classified into four levels.

The nine activities most frequently introduced at the regional level (between $42 \%$ and $82 \%$ of the sample) are implemented simultaneously by $15 \%$ of them. If we consider firms that undertake at least six of these nine activities, the percentage is $46.2 \%$, while if five activities are considered, the percentage of firms rises to $55.8 \%$.

\subsection{Discussion and implications for a cleaner production from a CE perspective}

Based on the main results achieved through the qualitative analysis of a regional study, we can argue that introduction of the CE in businesses remains in an early stage, and its measurement for the whole firm requires further investigation.

Environmental improvement towards circular business models is associated with change since it requires transformations in different areas of firms. Sustainability, moreover, requires coordinated change because the introduction of changes in a single business area is not enough (Del Río González, 2009). Indeed, partial measurement is not sufficient to understand the CE adoption by businesses; a greater transformation is required, affecting the entire organisation. Thus, given the increasing institutional pressure for the implementation of the CE (Zeng et al., 2017) and the pressure of stakeholder for reporting (Stewart and Niero, 2018), firms can analyse their level of adoption of the CE through the measurement of different activities related to the EC already being implemented. This approach to the 
Aranda-Usón, A., Portillo-Tarragona, P. Scarpellini, S., Llena-Macarulla, F. (2019 on-line) The progressive adoption of a circular economy by businesses for cleaner production: An approach from a regional study in Spain. Journal of Cleaner Production. Vol. 247(2020) 119648 - https://doi.org/10.1016/j.jclepro.2019.119648

measurement of the corporate CE, in line with Aranda-Usón et al. (2019), has been applied to a territory to analyse the main initiatives that could be planned by the regional government to encourage the CE among businesses (Scarpellini et al., 2019).

The results of this study indicate that CE-related activities are being adopted by companies progressively, from a small number to a greater number of simultaneous activities. This progressive adoption of the CE by businesses is not clearly related to the closing level of the material loops in terms of the CE. The activities that are usually introduced first by businesses are those with the lowest index of circularity. In facts, waste recycling and treatment are generally addressed first in the analysed region. Recycling has benefited from a large number of technological eco-innovations achieving greater efficiency, and this fact, along with sectoral regulation, has motivated companies to implement these activities (Scarpellini et al., 2016). Nevertheless, internal waste recycling in-house is not being implemented by companies mainly due to the regional regulations that limit such activities and promote the external management of waste through accredited and specialised firms (Portillo-Tarragona et al., 2017). Based on these results, it must be considered that the progressive approach to environmental strategy provides a continuum of possible behaviours -- based on a similar structure -- from passive or reactive to environmentally advanced or proactive strategies (Garcés-Ayerbe et al., 2016).

From another perspective, the opinions of experts and the data obtained from the companies surveyed are better aligned regarding the intermediate groups of activities, but the experts' opinions differ in certain respects from the results of the questionnaires collected from businesses about the CE-related activities that they consider relevant in the region. Most of the experts advocate the introduction of the circular model specifically to increase the level of the material loops closing, while the companies are introducing CE-related activities based on the volume of and return on the investment and are influenced by regulations and the market.

In summary, we observe that companies have widely implemented the activities in group I, which are considered first steps towards a more circular model. However, the regional experts interviewed do not identify the activities in group I as relevant, precisely because, in their opinions, businesses have already introduced them; these activities therefore bear less relation to a CE in terms of the closing of material loops. In many cases, companies have implemented the activities in group I to comply with regulations, due to the maturing of technologies or because the investments were profitable. Thus, as a result of this study to be 
Aranda-Usón, A., Portillo-Tarragona, P. Scarpellini, S., Llena-Macarulla, F. (2019 on-line) The progressive adoption of a circular economy by businesses for cleaner production: An approach from a regional study in Spain. Journal of Cleaner Production. Vol. 247(2020) 119648 - https://doi.org/10.1016/j.jclepro.2019.119648

discussed more deeply in future research, it can be argued that only firms with change processes of integrating a wide range of CE-related activities, industrial symbiosis or/and collaborative solutions can achieve the most advanced levels of a CE.

It is undoubtedly that factors such as the sectors in which companies operate, the production processes that they must implement and the volume of investment required influence the process of adoption of the CE by firms (Aranda-Usón et al., 2019; Scarpellini et al., 2018). However, spatial factors and legal frameworks across local, regional and national levels add an additional layer of complexity to introducing the CE into businesses. From a regional perspective, it is important, therefore, to encourage the engagement of companies with the $\mathrm{CE}$ and to alleviate the difficulty in making these investments (Katz Gerro and López Sintas, 2019). In addition, the measurement of specific impacts of the business $\mathrm{CE}$ on the territory allows for focusing on the general drivers of the $\mathrm{CE}$ identified by Ranta et al. (2018) from each institutional environment, regulatory measures, normative indicators and institutional support at the territorial level to influence CE development (Aranda-Usón et al., 2018).

In summary, there is no doubt that the implementation of standardised metrics for measuring the environmental impact of CE-related activities and their impacts on linear models is required, in line with what was recommended by Lacy and Hayward (2011). However, the results obtained in this study suggest that existing sources of information can be used as a first approach to measuring the level of circularity adopted by a firm as a whole, at least until more specific metrics can be applied. Taking into account that the introduction of the CE at the micro-level is in the initial stage, the CE metrics have to be defined from different perspectives depending on the scope of the analysis, such as regional or sectoral. The metrics proposed in this study can offer selected insight into a company's sustainability work since they outline key topics of the year, filtered by the company's communication team and according to stakeholders' concerns. (Ortas et al., 2019; Stewart and Niero, 2018) and corporate social responsibility (Zubeltzu-Jaka et al., 2018).While metrics and international standards are being developed for the $\mathrm{CE}$, companies can measure their progressive approaches to the circular model through existing internal indicators and their environmental accounting and reporting practices, facilitating the internal measurement of circularity, which companies can perform to improve their cleaner production practices.

\section{Conclusions}


Aranda-Usón, A., Portillo-Tarragona, P. Scarpellini, S., Llena-Macarulla, F. (2019 on-line) The progressive adoption of a circular economy by businesses for cleaner production: An approach from a regional study in Spain. Journal of Cleaner Production. Vol. 247(2020) 119648 - https://doi.org/10.1016/j.jclepro.2019.119648

In this paper, a qualitative analysis based on a regional study was performed to measure the level of adoption of different CE-related activities by businesses and their engagement in the CE from a regional perspective. To this end, the main CE-related activities that can currently be implemented by companies have been categorised in this study through interviews with representatives of main stakeholders to define the relevance of the CE for businesses in the region.

As a general remark, we affirm that the level of adoption of the CE by businesses can be measured using a set of indicators able to define the volume of the CE-related activities performed by businesses that are considered relevant in a given territory. A certain incremental tendency can be appreciated through analysis of the specific activities that have been introduced at the micro-level in terms of the CE. However, we cannot affirm that the $\mathrm{CE}$ is being adopted by businesses with the principal aim of closing the material loops.

This approach to the CE from the micro-level allows us to elucidate the progressive process of adoption of the $\mathrm{CE}$ undertaken by businesses, influenced by different factors intrinsic to the regional contexts in which firms are located. At the first level of the CE - for those activities mainly related to recycling or energy and resource efficiency, renewables and eco-design - the CE introduction in firms is influenced by the specific regulations in the region and institutional planning (Scarpellini and Romeo, 1999). In this specific study, it has been emphasised that regulations regarding renewables and waste treatment have limited the introduction of some of the key activities for the deployment of the CE frequently addressed in other European regions. In addition, the most advanced levels of circularity are not considered by the firms located in the region. Subsequently, the implementation of new activities by firms would be conditioned on the volume of investment, the degree of uncertainty (legal and/or financial), and the public initiatives undertaken by administrations to promote new collaborative actions between companies in the territory to promote a greater degree of circularity. We conclude that, to improve institutional support for the CE and allow it to fulfil its potential as a sustainable growth model, diversified institutional support for reducing the products manufactured and materials used, as well as increasing reuse, is needed.

The main contribution of this paper to the academic literature is the measurement of the $\mathrm{CE}$ adoption by businesses in the area of the environmental management accounting, providing information about the progressive process of change and pointing out how firms could evolve to more advanced stages of a CE. This study enhances our knowledge about the 
Aranda-Usón, A., Portillo-Tarragona, P. Scarpellini, S., Llena-Macarulla, F. (2019 on-line) The progressive adoption of a circular economy by businesses for cleaner production: An approach from a regional study in Spain. Journal of Cleaner Production. Vol. 247(2020) 119648 - https://doi.org/10.1016/j.jclepro.2019.119648

scarce introduction of the CE among businesses and offers empirical evidence for the great difficulty in measuring internal processes that depend on different factors and often differ between companies. The proposed measurement represents a first approach to the stakeholders' theoretical framework applied to the CE, i.e., that of a subject still underexplored in the literature.

For policy makers, the availability of specific information about the level of adoption of the CE by businesses in a territory facilitates the development of environmental regional plans to promote the CE through specific actions depending on the level of adoption of the CE by businesses located in the region. This perspective can reduce the time required to introduce the $\mathrm{CE}$ through environmental planning to foster the most advanced stage of cleaner production based on the $\mathrm{CE}$ principles in the regional context.

This study has also important implications for management because the different CErelated activities can be used as a tool for the environmental management accounting to achieve competitive advantages and to change those processes to integrate progressively the CE-related practices. The measurement in a common framework of the proposed indicatorsthat are being measured at present by most of the firms- facilitates the decision-making to adopt a more circular business model or to introduce new CE-related activities to achieve a more advanced stage of circularity. In addition, this integrated measurement provides more detailed information for the social corporate responsibility and the sustainability reporting in terms of CE and facilitates to practitioners the estimation of the firms' impacts in response to the institutional initiatives that promote the $\mathrm{CE}$ in the territory. Thus, the measurement of this process at a territorial level is a complementary knowledge for both, the managers responsible for the environmental accounting processes for designing and developing environmental strategy, and for policy-makers to evaluate their environmental planning actions.

This study is not exempt from limitations, mainly due to the difficulty of obtaining internal data from the firms and the geographic limitations of this regional study. The evolution of the $\mathrm{CE}$ in a broader and ongoing organisational framework requires further investigation and must be thoroughly discussed. The individual business interplaying with the regional government and its institutional inference have not been specifically addressed in this study. A future line of inquiry should investigate how the different levels of adoption of the CE by businesses can be scaled up to the regional level. 
Aranda-Usón, A., Portillo-Tarragona, P. Scarpellini, S., Llena-Macarulla, F. (2019 on-line) The progressive adoption of a circular economy by businesses for cleaner production: An approach from a regional study in Spain. Journal of Cleaner Production. Vol. 247(2020) 119648 - https://doi.org/10.1016/j.jclepro.2019.119648

Given its potential to provide information about corporate finance, environmental strategy, environmental management accounting, organisational issues, or the relations with stakeholders, now the CE literature at the micro level could be considered from both theoretical and applied environmental management angles and set different approaches for future research in the interrelation theoretical areas that the CE encompasses for cleaner production and sustainability.

\section{Acknowledgements}

This paper was made possible by funding from the Spanish Ministry of Economy, Industry and Competitiveness, Project “ECO-CIRCULAR” - Ref. ECO2016-74920-C2-1-R and was partially co-financed by the Regional Government of Aragón within the framework of the Research Group Ref.: S33_17R. We would like to express our special thanks to the experts and representatives of the entities who collaborated through semi-structured interviews in their fundamental roles as 'key informants' within the framework of the study financed by the Economic and Social Council of the Region of Aragón (CESA). We are particularly grateful for the contributions of the companies that participated in project ECO2013-45599-R and that provided the necessary data for this research.

\section{References}

Aranda-Usón, A., M. Moneva, J., Portillo-Tarragona, P., Llena-Macarulla, F., 2018. Measurement of the circular economy in businesses: Impact and implications for regional policies. Econ. Policy Energy Environ. 2, 187-205. doi:10.3280/EFE2018-002010

Aranda-Usón, A., Portillo-Tarragona, P., Marín-Vinuesa, L.M., Scarpellini, S., 2019. Financial Resources for the Circular Economy : A Perspective from Businesses. Sustainability 11, 1-23. doi:10.3390/su11030888

Bakker, C., Wang, F., Huisman, J., Den Hollander, M., 2014. Products that go round: Exploring product life extension through design. J. Clean. Prod. 69, 10-16. doi:10.1016/j.jclepro.2014.01.028

Banaitè, D., Tamošiūnienè, R., 2016. Sustainable Development: the Circular Economy Indicators' Selection Model. J. Secur. Sustain. Issues 6, 315-323. doi:10.9770/jssi.2016.6.2(10)

Bocken, N.M.P., de Pauw, I., Bakker, C., van der Grinten, B., 2016. Product design and business model strategies for a circular economy. J. Ind. Prod. Eng. 33, 308-320. doi:10.1080/21681015.2016.1172124

Camilleri, M.A., 2017. Corporate citizenship and social responsibility policies in the United States of America. Sustain. Accounting, Manag. Policy J. 8, 77-93. doi:10.1108/SAMPJ-05-2016-0023

Chen, X., Haight, M.E., Geng, Y., Fujita, T., 2010. Managing municipal solid waste from a system perspective: A comparative study of Dalian, China and Waterloo, Canada. Sustain. Dev. 18, 282-294. doi:10.1002/sd.479

Crossan, M.M., Lane, H.W., White, R.E., 1999. An Organizational Learning Freamwork: From Intuition to 
Aranda-Usón, A., Portillo-Tarragona, P. Scarpellini, S., Llena-Macarulla, F. (2019 on-line) The progressive adoption of a circular economy by businesses for cleaner production: An approach from a regional study in Spain. Journal of Cleaner Production. Vol. 247(2020) 119648 - https://doi.org/10.1016/j.jclepro.2019.119648

Institution. Acad. Manag. Rev. 24, 522-537. doi:10.5465/AMR.1999.2202135

Daddi, T., Nucci, B., Iraldo, F., 2017. Using Life Cycle Assessment (LCA) to measure the environmental benefits of industrial symbiosis in an industrial cluster of SMEs. J. Clean. Prod. 147, 157-164. doi:10.1016/j.jclepro.2017.01.090

Dajian, Z., 2008. Background, pattern and policy of China for developing circular economy. Chinese J. Popul. Resour. Environ. 6, 3-8. doi:10.1080/10042857.2008.10684889

de Jesus, A., Antunes, P., Santos, R., Mendonça, S., 2018. Eco-innovation in the transition to a circular economy: An analytical literature review. J. Clean. Prod. 172, 2999-3018. doi:10.1016/j.jclepro.2017.11.111

De los Rios, I.C., Charnley, F.J.S., 2017. Skills and capabilities for a sustainable and circular economy: The changing role of design. J. Clean. Prod. 160, 109-122. doi:10.1016/j.jclepro.2016.10.130

Del Río González, P., 2009. The empirical analysis of the determinants for environmental technological change: A research agenda. Ecol. Econ. 68, 861-878. doi:10.1016/j.ecolecon.2008.07.004

Despeisse, M., Kishita, Y., Nakano, M., Barwood, M., 2015. Towards a circular economy for end-of-life vehicles: A comparative study UK - Japan, in: Procedia CIRP. pp. 668-673. doi:10.1016/j.procir.2015.02.122

Di Maio, F., Rem, P.C., 2015. A Robust Indicator for Promoting Circular Economy through Recycling, in: Journal of Environmental Protection. pp. 1095-1104. doi:10.4236/jep.2015.610096

Dolowitz, D.P., Medearis, D., 2009. Considerations of the obstacles and opportunities to formalizing crossnational policy transfer to the United States: A case study of the transfer of urban environmental and planning policies from Germany. Environ. Plan. C Gov. Policy 27, 684-697. doi:10.1068/c0865j

Dong-her, S., Chia-Ming, L., Chia-Hao, L., Sin-Ye, C., Kuo-Jui, W., Ming-Lang, T., Shih, D.-H., Lu, C.-M., Lee, C.-H., Cai, S.-Y., Wu, K.-J., Tseng, M.-L., 2018. Eco-innovation in circular agri-business. Sustain. 10, 1-13. doi:10.3390/su10041140

Elia, V., Gnoni, M.G., Tornese, F., 2017. Measuring circular economy strategies through index methods: A critical analysis. J. Clean. Prod. 142, 2741-2751. doi:10.1016/j.jclepro.2016.10.196

Ellen MacArthur Foundation, Granta Design, 2015. Circularity Indicators. An approach to measuring circularity, Circular Indicators: An approach to measuring circularity. Methodology. doi:10.1016/j.giq.2006.04.004

European Commision, 2015. Communication form the Commission to the European Parliament, the Council, the European Economic and Social Committee of the Regions - Cloosing the loop -An EU action plan for the circular economy. COM/2015/0614 Final. doi:10.1017/CBO9781107415324.004

European Commission, 2018a. An European Strategy for Plastics in a Circular Economy - SWD(2018) 16 final. $\operatorname{COM}(2018) 28$ Final. Annex. 1 to 3.

European Commission, 2018b. EU-Report on Critical Raw Materials and the Circular Economy. SWD(2018) 36 final.

European Commission, 2016. European SMEs and the Circular Economy. European Union, Luxembourg. doi:10.2779/397947

Figge, F., Givry, P., Canning, L., Franklin-Johnson, E., Thorpe, A., 2017. Eco-efficiency of Virgin Resources: A Measure at the Interface Between Micro and Macro Levels. Ecol. Econ. 138, 12-21. doi:10.1016/j.ecolecon.2017.03.016

Fletcher, C.A., Hooper, P.D., Dunk, R.M., 2018. Unintended consequences of secondary legislation: A case 
Aranda-Usón, A., Portillo-Tarragona, P. Scarpellini, S., Llena-Macarulla, F. (2019 on-line) The progressive adoption of a circular economy by businesses for cleaner production: An approach from a regional study in Spain. Journal of Cleaner Production. Vol. 247(2020) 119648 - https://doi.org/10.1016/j.jclepro.2019.119648

study of the UK landfill tax (qualifying fines) order 2015. Resour. Conserv. Recycl. 138, 160-171. doi:10.1016/j.resconrec.2018.07.011

Franco, M.A., 2017. Circular economy at the micro level: A dynamic view of incumbents' struggles and challenges in the textile industry. J. Clean. Prod. 168, 833-845. doi:10.1016/j.jclepro.2017.09.056

Garcés-Ayerbe, C., Rivera-Torres, P., Suárez-Perales, I., Hiz, D.I.L.D. La, 2019. Is it possible to change from a linear to a circular economy? An overview of opportunities and barriers for european small and medium-sized enterprise companies. Int. J. Environ. Res. Public Health 16, 1-15. doi:10.3390/ijerph16050851

Garcés-Ayerbe, C., Scarpellini, S., Valero-Gil, J., Rivera-Torres, P., 2016. Proactive environmental strategy development: from laggard to eco-innovative firms. J. Organ. Chang. Manag. 29, 1-17. doi:10.1108/JOCM-05-2016-0081

Geissdoerfer, M., Savaget, P., Bocken, N.M.P., Hultink, E.J., 2017. The Circular Economy - A new sustainability paradigm? J. Clean. Prod. 143, 757-768. doi:10.1016/j.jclepro.2016.12.048

Geng, Y., Fu, J., Sarkis, J., Xue, B., 2012. Towards a national circular economy indicator system in China: An evaluation and critical analysis. J. Clean. Prod. 23, 216-224. doi:10.1016/j.jclepro.2011.07.005

Geng, Y., Zhu, Q., Doberstein, B., Fujita, T., 2009. Implementing China’s circular economy concept at the regional level: A review of progress in Dalian, China. Waste Manag. 29, 996-1002. doi:10.1016/j.wasman.2008.06.036

Gharfalkar, M., Court, R., Campbell, C., Ali, Z., Hillier, G., 2015. Analysis of waste hierarchy in the European waste directive 2008/98/EC. Waste Manag. 39, 305-313. doi:10.1016/j.wasman.2015.02.007

Ghisellini, P., Cialani, C., Ulgiati, S., 2016. A review on circular economy: The expected transition to a balanced interplay of environmental and economic systems. J. Clean. Prod. 114, 11-32. doi:10.1016/j.jclepro.2015.09.007

Ghisellini, P., Ji, X., Liu, G., Ulgiati, S., 2018. Evaluating the transition towards cleaner production in the construction and demolition sector of China: A review. J. Clean. Prod. 195, 418-434. doi:10.1016/j.jclepro.2018.05.084

Gimeno, J.Á., Llera, E., Scarpellini, S., 2018. Investment Determinants in Self-Consumption Facilities: Characterization and Qualitative Analysis in Spain. Energies 11, 2178. doi:10.3390/en11082178

Gobierno de Aragón, 2015. Estrategia Aragonesa de Investigación e Innovación para unaEspecialización Inteligente RIS3 Aragón.

Govindan, K., Hasanagic, M., 2018. A systematic review on drivers, barriers, and practices towards circular economy: a supply chain perspective. Int. J. Prod. Res. 56, 278-311. doi:10.1080/00207543.2017.1402141

Hu, Y., He, X., Poustie, M., 2018. Can legislation promote a circular economy? A material flow-based evaluation of the circular degree of the Chinese economy. Sustain. 10. doi:10.3390/su10040990

Huysman, S., De Schaepmeester, J., Ragaert, K., Dewulf, J., De Meester, S., 2017. Performance indicators for a circular economy: A case study on post-industrial plastic waste. Resour. Conserv. Recycl. 120, 46-54. doi:10.1016/j.resconrec.2017.01.013

Kalmykova, Y., Sadagopan, M., Rosado, L., 2018. Circular economy - From review of theories and practices to development of implementation tools. Resour. Conserv. Recycl. 135, 190-201. doi:10.1016/j.resconrec.2017.10.034

Kama, K., 2015. Circling the economy: Resource-making and marketization in EU electronic waste policy. 
Aranda-Usón, A., Portillo-Tarragona, P. Scarpellini, S., Llena-Macarulla, F. (2019 on-line) The progressive adoption of a circular economy by businesses for cleaner production: An approach from a regional study in Spain. Journal of Cleaner Production. Vol. 247(2020) 119648 - https://doi.org/10.1016/j.jclepro.2019.119648

Area 47, 16-23. doi:10.1111/area.12143

Katz Gerro, T., López Sintas, J., 2019. Mapping circular economy activities in the European Union: Patterns of implementation and their correlates in small and medium-sized enterprises. Bus. Strateg. Environ. 28, 485-496. doi:10.1002/bse.2259

Kirchherr, J., Reike, D., Hekkert, M., 2017. Conceptualizing the circular economy: An analysis of 114 definitions. Resour. Conserv. Recycl. 127, 221-232. doi:10.1016/j.resconrec.2017.09.005

Korhonen, J., Honkasalo, A., Seppälä, J., 2018. Circular Economy: The Concept and its Limitations. Ecol. Econ. 143, 37-46. doi:10.1016/j.ecolecon.2017.06.041

Lacy, P., Hayward, R., 2011. A new era of sustainability in emerging markets? Insights from a global CEO study by the United Nations Global Compact and Accenture. Corp. Gov. 11, 348-357. doi:10.1108/14720701111159208

Lewandowski, M., 2016. Designing the business models for circular economy-towards the conceptual framework. Sustain. 8, 1-28. doi:10.3390/su8010043

Li, H., Bao, W., Xiu, C., Zhang, Y., Xu, H., 2010. Energy conservation and circular economy in China’s process industries. Energy 35, 4273-4281. doi:10.1016/j.energy.2009.04.021

Lieder, M., Rashid, A., 2016. Towards circular economy implementation: A comprehensive review in context of manufacturing industry. J. Clean. Prod. 115, 36-51. doi:10.1016/j.jclepro.2015.12.042

Linder, M., Sarasini, S., van Loon, P., 2017. A Metric for Quantifying Product-Level Circularity. J. Ind. Ecol. 21, 545-558. doi:10.1111/jiec.12552

Liu, Y., Bai, Y., 2014. An exploration of firms’ awareness and behavior of developing circular economy: An empirical research in China. Resour. Conserv. Recycl. 87, 145-152. doi:10.1016/j.resconrec.2014.04.002

Liu, Y.S., Yang, J.H., 2018. A longitudinal analysis of corporate greenhouse gas disclosure strategy. Corp. Gov. Int. J. Bus. Soc. 18, 317-330. doi:10.1108/CG-11-2016-0213

Manninen, K., Koskela, S., Antikainen, R., Bocken, N., Dahlbo, H., Aminoff, A., 2018. Do circular economy business models capture intended environmental value propositions? J. Clean. Prod. 171, 413-422. doi:10.1016/j.jclepro.2017.10.003

Marco-Fondevila, M., Moneva Abadía, J.M., Scarpellini, S., 2018. CSR and green economy: Determinants and correlation of firms’ sustainable development. Corp. Soc. Responsib. Environ. Manag. 25, 1-16. doi:10.1002/csr.1492

Marco, M., Moneva, J.M., Scarpellini, S., 2019. Environmental disclosure and Eco-innovation interrelation . The case of Spanish firms. Spanish Account. Rev. 22, 71-85.

Masi, D., Day, S., Godsell, J., 2017. Supply Chain Configurations in the Circular Economy: A Systematic Literature Review. Sustainability 9, 1602. doi:10.3390/su9091602

Mathews, J.A., Tan, H., 2011. Progress Toward a Circular Economy in China. J. Ind. Ecol. 15, 435-457. doi:10.1111/j.1530-9290.2011.00332.x

Merli, R., Preziosi, M., Acampora, A., 2018. How do scholars approach the circular economy? A systematic literature review. J. Clean. Prod. 178, 703-722. doi:10.1016/j.jclepro.2017.12.112

Miroshnychenko, I., Barontini, R., Testa, F., 2017. Green practices and financial performance: A global outlook. J. Clean. Prod. 147, 340-351. doi:10.1016/j.jclepro.2017.01.058

Moktadir, M.A., Rahman, T., Rahman, M.H., Ali, S.M., Paul, S.K., 2018. Drivers to sustainable manufacturing practices and circular economy: A perspective of leather industries in Bangladesh. J. 
Aranda-Usón, A., Portillo-Tarragona, P. Scarpellini, S., Llena-Macarulla, F. (2019 on-line) The progressive adoption of a circular economy by businesses for cleaner production: An approach from a regional study in Spain. Journal of Cleaner Production. Vol. 247(2020) 119648 - https://doi.org/10.1016/j.jclepro.2019.119648

Clean. Prod. 174, 1366-1380. doi:10.1016/j.jclepro.2017.11.063

Moreno, De los Rios, C., Rowe, Z., Charnley, F., 2016. A conceptual framework for circular design. Sustain. 8, 2-15. doi:10.3390/su8090937

Murray, A., Skene, K., Haynes, K., 2017. The Circular Economy: An Interdisciplinary Exploration of the Concept and Application in a Global Context. J. Bus. Ethics 140, 369-380. doi:10.1007/s10551-0152693-2

Ormazabal, M., Prieto-Sandoval, V., Puga-Leal, R., Jaca, C., 2018. Circular Economy in Spanish SMEs: Challenges and opportunities. J. Clean. Prod. 185, 157-167. doi:10.1016/j.jclepro.2018.03.031

Ortas, E., Gallego-Álvarez, I., Álvarez, I., 2019. National institutions, stakeholder engagement, and firms’ environmental, social, and governance performance. Corp. Soc. Responsib. Environ. Manag. 26, 598611. doi:10.1002/csr.1706

Pieroni, M.P.P., McAloone, T.C., Pigosso, D.C.A., 2019. Business model innovation for circular economy and sustainability: A review of approaches. J. Clean. Prod. 2015, 198-216. doi:10.1016/j.jclepro.2019.01.036

Pomponi, F., Moncaster, A., 2017. Circular economy for the built environment: A research framework. J. Clean. Prod. 143, 710-718. doi:10.1016/j.jclepro.2016.12.055

Portillo-Tarragona, P., Scarpellini, S., Llena, F., Aranda-Usón, A., 2017. Nivel de implantación de la economía circular en Aragón. (C) Consejo Económico y Social de Aragón, Zaragoza (Spain).

Portillo-Tarragona, P., Scarpellini, S., Moneva, J., Valero-Gil, J., Aranda-Usón, A., 2018. Classification and Measurement of the Firms’ Resources and Capabilities Applied to Eco-Innovation Projects from a Resource-Based View Perspective. Sustainability 10, 3161. doi:10.3390/su10093161

Prieto-Sandoval, V., Jaca, C., Ormazabal, M., 2018. Towards a consensus on the circular economy. J. Clean. Prod. 179, 605-615. doi:10.1016/j.jclepro.2017.12.224

Ranta, V., Aarikka-Stenroos, L., Ritala, P., Mäkinen, S.J., 2018. Exploring institutional drivers and barriers of the circular economy: A cross-regional comparison of China, the US, and Europe. Resour. Conserv. Recycl. 135, 70-82. doi:10.1016/j.resconrec.2017.08.017

Reike, D., Vermeulen, W.J.V., Witjes, S., 2018. The circular economy: New or Refurbished as CE 3.0? Exploring Controversies in the Conceptualization of the Circular Economy through a Focus on History and Resource Value Retention Options. Resour. Conserv. Recycl. 135, 246-264. doi:10.1016/j.resconrec.2017.08.027

Rivera-Torres, P., Garces-Ayerbe, C., Scarpellini, S., Valero-Gil, J., 2015. Pro-Environmental Change and Short- to Mid-Term Economic Performance: The Mediating Effect of Organisational Design Change. Organ. Environ. 28, 307-327. doi:10.1177/1086026615603867

Santolaria, M., Oliver-Sol, J., Gasol, C.M., Morales-Pinzón, T., Rieradevall, J., 2011. Eco-design in innovation driven companies: Perception, predictions and the main drivers of integration. the Spanish example. J. Clean. Prod. 19, 1315-1323. doi:10.1016/j.jclepro.2011.03.009

Scarpellini, S., Marín-Vinuesa, L.M., Portillo-Tarragona, P., Moneva, J.M., 2018. Defining and measuring different dimensions of financial resources for business eco-innovation and the influence of the firms' capabilities. J. Clean. Prod. 204, 258-269. doi:10.1016/j.jclepro.2018.08.320

Scarpellini, S., Portillo-Tarragona, P., Aranda-Usón, A., Llena-Macarulla, F., 2019. Definition and measurement of the circular economy’s regional impact. J. Environ. Plan. Manag. 62, 2211-2237. doi:10.1080/09640568.2018.1537974 
Aranda-Usón, A., Portillo-Tarragona, P. Scarpellini, S., Llena-Macarulla, F. (2019 on-line) The progressive adoption of a circular economy by businesses for cleaner production: An approach from a regional study in Spain. Journal of Cleaner Production. Vol. 247(2020) 119648 - https://doi.org/10.1016/j.jclepro.2019.119648

Scarpellini, S., Romeo, L.M., 1999. Policies for the setting up of alternative energy systems in European SMEs: a case study. Energy Convers. Manag. 40, 1661-1668. doi:10.1016/S0196-8904(99)00059-X

Scarpellini, S., Valero-Gil, J., Portillo-Tarragona, P., 2016. The ‘economic-finance interface’ for ecoinnovation projects. Int. J. Proj. Manag. 34, 1012-1025. doi:10.1016/j.ijproman.2016.04.005

Singh, J., Ordóñez, I., 2016. Resource recovery from post-consumer waste: important lessons for the upcoming circular economy. J. Clean. Prod. 134, 342-353. doi:10.1016/j.jclepro.2015.12.020

Smol, M., Kulczycka, J., Avdiushchenko, A., 2017. Circular economy indicators in relation to eco-innovation in European regions. Clean Technol. Environ. Policy 19, 669-678. doi:10.1007/s10098-016-1323-8

Stahel, W.R., 2013. Policy for material efficiency--sustainable taxation as a departure from the throwaway society. Philos. Trans. R. Soc. A Math. Phys. Eng. Sci. 371, 20110567-20110567. doi:10.1098/rsta.2011.0567

Stewart, R., Niero, M., 2018. Circular economy in corporate sustainability strategies: A review of corporate sustainability reports in the fast-moving consumer goods sector. Bus. Strateg. Environ. 27, 1005-1022. doi:10.1002/bse.2048

Urbinati, A., Chiaroni, D., Chiesa, V., 2017. Towards a new taxonomy of circular economy business models. J. Clean. Prod. 168, 487-498. doi:10.1016/j.jclepro.2017.09.047

Van Berkel, R., Fujita, T., Hashimoto, S., Fujii, M., 2009. Quantitative Assessment of Urban and Industrial Symbiosis in Kawasaki, Japan. Environ. Sci. Technol. 43, 1271-1281. doi:10.1021/es803319r

Walendowski, J., Roman, L., Miedzinski, M., 2014. Regional Innovation Monitor Plus. Regions in transition towards a circular economy.

Walls, J.L., Paquin, R.L., 2015. Organizational Perspectives of Industrial Symbiosis: A Review and Synthesis. Organ. Environ. 28, 32-53. doi:10.1177/1086026615575333

Winkler, H., 2011. Closed-loop production systems - A sustainable supply chain approach. CIRP J. Manuf. Sci. Technol. 4, 243-246. doi:10.1016/j.cirpj.2011.05.001

Witjes, S., Lozano, R., 2016. Towards a more Circular Economy: Proposing a framework linking sustainable public procurement and sustainable business models. Resour. Conserv. Recycl. 112, 37-44. doi:10.1016/j.resconrec.2016.04.015

Yang, S., Feng, N., 2008. A case study of industrial symbiosis: Nanning Sugar Co., Ltd. in China. Resour. Conserv. Recycl. 52, 813-820. doi:10.1016/j.resconrec.2007.11.008

Yi, H., Liu, Y., 2015. Green economy in China: Regional variations and policy drivers. Glob. Environ. Chang. 31, 11-19. doi:10.1016/j.gloenvcha.2014.12.001

Yuan, Z., Bi, J., Moriguichi, Y., 2006. The Circular Economy: A New Development Strategy in China. J. Ind. Ecol. 10, 4-8. doi:10.1162/108819806775545321

Zamfir, A.-M., Mocanu, C., Grigorescu, A., 2017. Circular Economy and Decision Models among European SMEs. Sustainability 9, 1507. doi:10.3390/su9091507

Zeng, H., Chen, X., Xiao, X., Zhou, Z., 2017. Institutional pressures, sustainable supply chain management, and circular economy capability: Empirical evidence from Chinese eco-industrial park firms. J. Clean. Prod. 155, 54-65. doi:10.1016/j.jclepro.2016.10.093

Zhu, Q., Geng, Y., Sarkis, J., Lai, K.H., 2014. Barriers to promoting eco-lndustrial parks development in China: Perspectives from senior officials at National Industrial Parks. J. Ind. Ecol. 19, 457-467. doi:10.1111/jiec.12176

Zink, T., Geyer, R., 2017. Circular Economy Rebound. J. Ind. Ecol. 21, 593-602. doi:10.1111/jiec.12545 
Aranda-Usón, A., Portillo-Tarragona, P. Scarpellini, S., Llena-Macarulla, F. (2019 on-line) The progressive adoption of a circular economy by businesses for cleaner production: An approach from a regional study in Spain. Journal of Cleaner Production. Vol. 247(2020) 119648 - https://doi.org/10.1016/j.jclepro.2019.119648

Zubeltzu-Jaka, E., Andicoechea-Arondo, L., Alvarez Etxeberria, I., 2018. Corporate social responsibility and corporate governance and corporate financial performance: Bridging concepts for a more ethical business model. Bus. Strateg. Dev. 1, 214-222. doi:10.1002/bsd2.29

\title{
8. Annex
} \\ Public \\ Regional Government - Directorate-General for the Economy \\ Administration \\ Regional Government - Directorate-General for Sustainability and Rural Development \\ Regional Technology Institute \\ Public Institute for Electronic Administration \\ Public Institute for Water Management \\ Regional Media \\ ONGs Specialising in Environmental Sustainability \\ Consumers' Organisation \\ Society Sustainable Buildings Expert \\ R\&D - University Institute \\ Labour Union \\ Sociology Expert \\ Large Private Industry - Manufacturing Sector \\ Private \\ Association of Firms in the Building Sector \\ Company/ \\ Organisation \\ Medium Private Company - Chemical Sector \\ Private company - Electronic Devices Sector \\ Small Private Company - Industrial Sector \\ Private Renewables Company \\ Large Private Organisation - Waste Sector
}

Table 9. List of the 21 entities that collaborated through semi-structured interviews, classified into three categories. 